\title{
The Role of Baitul Arqom in Developing Islamic Character Education
}

\author{
Rahmatika Nur Aisyah W.P* \\ Guidance and Counseling \\ Universitas Negeri Yogyakarta \\ Yogyakarta, Indonesia \\ aisyahwindra@gmail.com*
}

\author{
Rita Eka Izzaty \\ Psychology \\ Universitas Negeri Yogyakarta \\ Yogyakarta, Indonesia \\ rita_ekaizzaty@uny.ac.id
}

\begin{abstract}
The purpose of this study is to describe the role of Baitul Arqom in instilling the foundation of Islamic character at the level of high school students. In this study the problem examined is the role of Baitul Arqom in instilling the Islamic character foundation of Muhammadiyah 1 Yogyakarta High School Students. The method used in this study is a qualitative research method. While the data analysis method used is descriptive qualitative method by inductive thinking. Based on the results of research and data analysis, it can be concluded that: Baitul Arqom has a role in providing guidance and coaching for students of Muhammadiyah 1 Yogyakarta High School in strengthening the foundations of Islamic character, both in the fields of Aqeedah, Morals, and Worship. All three are the main foundation in forming students with Islamic character.
\end{abstract}

Keywords-baitul arqom, islamic character education

\section{INTRODUCTION}

Education and character building are the responsibility of all parties. Character is important and fundamental for human life. Character has been inherent in human beings and shown in everyday behavior. Behaviors that have strong character and individually and socially are those who have good character, morals and character. Character like this that should be possessed by every individual to become a man of character [1]. Understanding of good character is a character that describes the behavior of a beautiful, girl, not evil that is about behavior and character in someone to do good and virtue. While a strong character that is the character who do not easily shaken or not easily affected, firm in faith, the establishment of, his willingness to, capable of and the power to do something, and had the advantage or proficiency in the knowledge.

In this case SMA Muhammadiyah 1 Yogyakarta in central java together of the program ismuba and of counseling held a special event of so as to render it a muslim who berakhlaqul order to , to hold a character education students made it a prestige issue islamic namely with existence of has the annual activity baitul arqom for new students. The arqom are the activities education training religious to infuse foundation character islam as well as motivate to be generation muslim responsible for himself and the community. Strong character in the field of aqeedah, morals, worship, reading the Qur'an and can develop the nature of honesty, courage, confidence, and responsibility in developing the studio.

The definition of character according is the quality or strength of mental or moral, moral or individual character which is a special personality that becomes the driving force and mobilizer and distinguishes other individuals [2]. Islamic character education is very important for students, because internalizing the foundations of Islamic character in students will have an impact on the harmonious school environment and bring good influence. In connection with the above, the writer is interested in conducting research on how the role of Baitul Arqom in instilling the Islamic character foundation of Muhammadiyah 1 Yogyakarta high school students.

\section{METHODS}

This type of research is field research, because this activity is carried out in the research environment, the approach used is a descriptive approach which is a research method that aims to collect data, facts and describe thoroughly and thoroughly in accordance with the issues to be resolved [3]. Descriptive data are generally collected through surveys, questionnaires, interviews, or observations [4]. The form of this research approach is to use descriptive qualitative analysis.

In this study the primary data source in question is in the form of interviews with the Baitul Arqom committee about the Role of Baitul Arqom Education in instilling the Islamic character foundation of Muhammadiyah 1 High School students in Yogyakarta who participated in Baitul Arqom activities. Interview with Ustadz Fauzi as chairman of Baitul Arqom. While the secondary data sources referred to in this research are documentation of Baitul Arqom education activities and field observations (environment and facilities and infrastructure in supporting the Baitul Arqom education process). Secondary data is obtained from the data on the implementation of Baitul Arqom.

Data collection methods: (1) interviews This method is used to obtain data from the Baitul Arqom committee team (chairman, teacher in charge, cleric for activities) students who take Baitul Arqom activities in Muhammdiyah 1 Yogyakarta High School; (2) observation, methods This is used to determine the geographical location, facilities and infrastructure in supporting the education of Baitul Arqom; 
(3) documentation, this method is used to find documentation data about the general description of Baitul Arqom Education in Muhammadiyah 1 Yogyakarta High School; (4) questionnaire, in this case the author views the questionnaire as the most practical instrument for collecting data related to the role of Baitul Arqom's education in shaping the character of students after attending Baitul Arqom's education.

The method analysis of the data that in use is qualitative analysis descriptive. After data collected, so the next step is to analyzed data, the technique of data available for analysis that is to analyzed data that which has accrued to be drawn a conclusion. The steps used are collecting data, reducing data, presenting data and collecting verification conclusions $[3,4]$. First, after the merging of data is complete, the authors do data reduction that is classifying, directing, removing unnecessary and organizing so that the data is disaggregated. Second, the reduced data will be presented in narrative form. Third, conclusions are drawn from the data presented in the second session with conclusions drawn.

\section{RESULT AND DISCUSSION}

Result

Development of Islamic Character Education in shaping Muslims who are trying in an educational or school environment requires several aspects to support the character of Islam. From the results of an interview with Ustad Fauzi as chairperson of the Baitul Arqom Muhammadiyah 1 Yogyakarta High School:

\section{A. Aqidah Aspects}

Baitul Arqom activity became one of the media in fostering true belief in students about the understanding of Aqeedah as taught by Rasulullah SAW.

\section{B. Ibadah Aspects}

In the implementation of Baitul Arqom very intensive in organizing religious education, in the Baitul Arqom activities the head of the committee always coordinates in guiding and controlling students during the Baitul Arqom activities.

\section{Akhlak Aspects}

In Baitul Arqom activities teach material morality to God, morality towards fellow human beings, morality towards animals, morality for plants, and also teaches dress ethics, as one of the provisions for students in carrying out their daily lives to reflect those who have noble character. By teaching moral education material, students are expected to become students who have noble character in accordance with the vision of Baitul Arqom, which is to form humans.

The role of Baitul Arqom in the formation of students' Islamic Characters including intensive Coaching by Facilitators, Imam Training and teachers in educating, providing material that is able to motivate students of Muhammadiyah 1 High School Yogyakarta to practice worship according to Muhammadiyah guidance, and supervise attitudes or behavior students during the Baitul Arqom activities.
Provisions for students in daily life so that people have noble character. With the teaching material of student education, students must have characters that are in accordance with the vision of Baitul Arqom who formed our human beings.

Discussion

Furqon Hidayatullah character is the quality or mental or moral strength, character or character of individuals who become special personalities who become drivers and movers, as well as differentiating from other individuals [2]. Character is often equated with character, someone gives character or character, if it has succeeded in gathering value from the beliefs that are used by the community as used morally in improving [5]. According character is interpreted as a basic value that builds a person's personality, formed well because it affects heredity and also influences the environment, which distinguishes from others and is created to adjust and behavior in everyday life [6]. According that the character is the original state that exists in individuals who distinguish between themselves and others [7].

Based on the theories of various figures above, it can be concluded that Islamic character education is a process undertaken to foster traits that are useful and beneficial in improving the quality or mental or moral strength, character or individual character, which is a special personality that becomes driving and driving, which distinguishes from other individuals, and is manifested in their attitudes and behavior in everyday life. To achieve Islamic character education required supporting activities one of which with Baitul Arqom.

In building a person's character in the world of education it takes the foundations that support the character in a person so that in everyday life is able to reflect the noble attitude as demonstrated by the Prophet. In building this foundation begins with strengthening some of the main aspects in the formation of an Islamic character which is approved from Aqeedah, Worship, Morals. There are many factors that highlight human character, character, morals, character and ethics. Of the many factors, the experts classify them into two parts, namely internal factors and external factors.

\section{CONCLUSION}

Based on research results Role Baitul Arqom in the Formation of Islamic Characters Muhammadiyah 1 Yogyakarta high school students can argue that Baitul Arqom has a role in providing guidance and coaching students of Muhammadiyah 1 High School Yogyakarta in the framework of the foundation of Islamic character, both in the field of Aqidah, Morals, and Worship. All three are the main foundation in forming students with Islamic character.

\section{REFERENCES}

[1] Ali, Mohammad Daud. 2010. Pendidikan Agama Islam. Jakarta: PT Raja Grafindo Persada

[2] Hidayatullah, Furqon. 2010. Pendidikan Karakter: Membangun Peradaban Bangsa, Surakarta. Yuma Pustaka.J

[3] Arikunto, Suharsimi. 1993. Prosedur Penelitian suatu Pendekatan Praktik. Jakarta: Rineka Cipta

[4] Arikunto, Suharsimi. 2010. Prosedur Penelitian suatu Pendekatan Praktik edisi revisi. Jakarta: Rineka Cipta. 
[5] Zuriah, Nurul. 2007. Pendidikan Moral dan Budi Pekerti Dalam Perspektif Perubahan. Jakarta: PT Bumi Aksara.

[6] Hamid, Hamdani. 2013. Pendidikan Karakter Perspektif Islam. Pustaka Setia: Bandung.
[7] Gunawan, Heri. 2012. Pendidikan Karakter Konsep Dan Implementasi. Bandung. 